\title{
Ta splanchna: A theopaschitic approach to a hermeneutics of God's praxis. From zombie categories to passion categories in theory formation for a practical theology of the intestines
}

\author{
Author: \\ Daniel J. Louw ${ }^{1}$ \\ Affiliation: \\ ${ }^{1}$ Department of Practical \\ Theology and Missiology, \\ Stellenbosch University, \\ South Africa \\ Correspondence to: \\ Daniel Louw \\ Email: \\ djl@sun.ac.za \\ Postal address: \\ 171 Dorp Street, \\ Stellenbosch 7600, \\ South Africa \\ Dates: \\ Received: 16 May 2011 \\ Accepted: 27 June 2011 \\ Published: 04 Nov. 2011 \\ How to cite this article: \\ Louw, D.J., 2011, 'Ta \\ splanchna: A theopaschitic \\ approach to a hermeneutics \\ of God's praxis. From \\ zombie categories to \\ passion categories in theory \\ formation for a practical \\ theology of the intestines', \\ HTS Teologiese Studies/ \\ Theological Studies 67(3), \\ Art. \#1087, 13 pages. http:// \\ dx.doi.org/10.4102/hts. \\ v67i3.1087
}

C 2011. The Authors.

Licensee: AOSIS

OpenJournals. This work

is licensed under the

Creative Commons

Attribution License.
It is argued that both the traditional clerical paradigm of an ecclesial approach and the phenomenological paradigm of an empirical approach are not sufficient enough to describe and maintain a theological methodology in practical theology. This has led to the introduction of a theopaschitic paradigm in theory formation. It is argued that the normative task of practical theology implies a philosophical-hermeneutical dimension, that is, to interpret under girding paradigms as related to meaning and being. It also implies a theological dimension; to reflect theologically on the praxis of God as an influential factor within human actions (inhabitational theology.) With reference to 'the pneumatological praxis of God', a practical theology of the intestines is proposed. Bowel categories reveal a divine intentionality (teleology) and describe a modus of God's praxis, the how of God within the vulnerability and suffering of human beings. This divine ontological mode should operate as a practical theological paradigm determining being qualities (ontic status) within human actions and processes of communication. The under girding theological presupposition is that ta splanchna [strong feeling of mercy and compassion expressed by the intestines] denotes a compassionate praxis of co-suffering (the passio Dei). Passion in practical theology emanates in parrhesia and instills a vivid hope: fides quaerens spem [faith in search of hope].

\section{Introduction}

I still recall how practical theology was formulated in the sixties at the faculty of theology in Stellenbosch. It was mainly within the clerical paradigm with the focus on the offices in the church. Praxis was mostly determined by the homiletic paradigm with the focus on kerygma, proclamation, prophetic calling and evangelistic expansion.

At the time the struggle for a new approach to practical theological reflection focused mainly on the ecclesial paradigm. The focal point was the official ministry of the church within the framework of 'reformed theology': the service to the Word ${ }^{1}$. New directions in practical theology were to a large extent an attempt to 'save' the office of lay people from the authority of the clergy. However, the dominating paradigm was the formal offices of the minister, the elder and the deacon ${ }^{2}$ as connected to the authority of the word, sacrament and discipline.

To a large extent practical theological thinking was dominated by the agenda of orthodox thinking: right and true doctrine. It was very rational. One can even say very positivistic because the impression was that one could detect a 'true God' through confessional formulations, as well as a 'true church' by means of doctrinal reflection. The main objective in theological reflection was rather to formulate the essence of a triune God and to maintain the internal and denominational well-being of the 'true church' in order to prevent any form of heresy, than to reflect on the mode of God's being within the realm of human suffering ${ }^{3}$, discrimination and stigmatisation.

\section{Looking back}

\section{Reformed tradition and the South African scenario ${ }^{4}$}

In general the theological discourse during the sixties and seventies was dominated by the threat of secularism (Cox 1967), the death of God debate (Vahanian 1961), and the attempt

1.See 'In diens van die Woord' from Jonker (1981).

2.The approach was personal and individualistic. The intention of praxis-thinking was the salvation of a human soul. The obsession in ministry was to make sure that faith is correct (true) (orthodoxy) and absolutely secure.

3.During my theological studies in 1966-1969 the study of Moltmann's theology of the cross was a forbidden subject. Even Barth was out. The dogmatic emphasis was on Bavinck.

4. With this article I want to honour Theuns Dreyer for his contribution to theory formation in practical theology. The critical question will be posed whether the ecclesial paradigm is still appropriate for doing practical theology within an interdisciplinary approach. 
of the so-called liberal theologians to deconstruct traditional theism ${ }^{5}$.

The context of ministry was the realm of the saeculum [the world] out there. The burning ecclesiological question in most evangelistic outreaches was quantitative: how can the mainline churches maintain their dominating and influential position in society; how many souls can be saved and captured for the kingdom of God? Ministerial success and effective practical theological models for ministry evolved around questions regarding the size of a congregation and how many people attended a church sermon. Ministry was a soul-winning endeavour within the paradigm of ecclesial maintenance. In pastoral care (cura animarum) the dominant paradigm within the reformed tradition was the kerygmatic paradigm, highly influenced by Eduard Thurneyson's Die Lehre von der Seelsorge (Thurneyson 1957) ${ }^{6}$.

During the seventies the overall paradigm in the Society for Practical Theology in South Africa was mostly the clerical paradigm. At the annual meetings the main emphasis was on the offices of the church and the proclamation of the Word ${ }^{7}$. Practical theology was understood as diaconiology: the practice of service to the word' and care for the individual spiritual needs of people (soul care).

At the end of the seventies I wrote a book titled Die Stad in die Mens. It was an attempt to reflect anew on the praxis of ministry within an urban setting. I then warned against the evangelistic emphasis on mass conversions within the American style of evangelism. The latter was often fueled by the enthusiasm of revivalism and the indirect intention to maintain the golden era of the corpus christianum [Christian world] with all its powerful and imperialistic ecclesial advantages (Louw 1980:34). I proposed a systems approach and group ministry within the public context of society, business and industry. The emphasis was on the office of the so-called 'lay people' in the church. To my mind this model for 'city evangelism' received no audience in practical theology due to the existing paradigm of ecclesial service ${ }^{8}$. Within theory formation practical theology was understood as the ministerial actions of the church?.

At that time I thought it was imperative for the church to move from the formal clerical paradigm to the informal koinonia-paradigm [intimate participation and mutual

5.God as a Deus ex machina; Robinson (1963.9) regarding the end of theism. 'But the centre of today's debate is concerned not with the relation of particular the centre of today's debate is concerned not with the relation of particular
myths to history, but with how far Christianity is committed to a mythological, or myths to history, but with how far Christianity is committed to a
supranaturalist, picture of the universe at all' (Robinson 1963:330).

6.In the Theology faculty of Stellenbosch the text of Thurneyson was prescribed during the sixties and the beginning of the seventies for students in pastoral care.

7.Dreyer (1981:6-7) described at that time that the object of study of practical theology is the church in her proclamation: 'die kerk as verkondigingsagent'; 'Met verkondiging bedoel ons die oordrag of bediening van die Woord aan mense, soos wat dit aan die kerk opgedra is'; 'Die praktiese teologie is nie bloot praktiese wenk wat dit aan die kerk opgedra is'; 'Die praktiese teologie is nie bloot praktiese wenke het die kerklike verkondiging as studie objek', Dreyer (1981:5). See the influence of Karl Barth in this regard, Dreyer (1981:4).

8.See inter alia the emphasis of De Klerk (1979:15).

9.See 'Handelinge van die kerk', Pieterse (1981:142) on the method of practical theology. sharing fellowship] of base groups or small cell groups ${ }^{10}$. I was influenced by Moltmann's book Kirche in der Kraft des Geistes (1975). With his emphasis on a God-image reframed by Freundschaft (1975:34-135) he advocated for an ecclesiology in terms of base congregations and the theological understanding of the fellowship in Christ as an event of the Spirit in society Ecclesiology is essentially a pneumatological event (Moltmann 1975:3) outside the formal structures of denominationalism.

From the North Americas came the very popular book of Girard Brethren Hang Loose (1972). I still recall other publications such as Casteel's Spiritual Renewal through Personal Groups (1967); Reid's Groups Alive - Church Alive (1969) and Stollberg's Seelsorge durch die Gruppe (1971). They all proposed a kind of ecclesiology beyond the denominational construct of the authority of the institutional offices of the church.

The evangelistic praxis of the church ${ }^{11}$ functioned mostly under the spell of what one can call the Constantine exploitation of power (Hall 1993:106). The gospel and the church were viewed as something that has to be established as an empire. As Hall (1993:106) pointed out: to sustain the power of an authoritative powerful church-praxis every form of tenderness and weakness is deleted because weakness is not 'the blueprint for a god designed for empire'. A very specific understanding of both the power of the church and the power of God fed this imperialistic thinking. God was the masculine patriarch of civil society, an omnipotent 'Caesar'12 who can do everything. He was interpreted as an immutable principle of life, which acts as the metaphysical cause of everything that befalls us and happens in life. Under the umbrella of this very omnipotent God the church functioned as a political enterprise that could prescribe the policy of governments ${ }^{13}$.

In 1988 Coenie Burger launched a research project on the position of practical theology in South Africa. He identified three basic approaches:

- The confessional approach regards Scripture as the only source of knowledge. Jonker (1983:81) referred to the fact that practical theology should use a deductive method to reveal the truth of God's word. Practical theology therefore applies a 'veritative reasoning'; it is an attempt to analyse

10.Within the South African Society of Practical Theology Barnard already in 1979 (pp 125-146) emphasised the importance of a group approach in ecclesiology.

11.In terms of a practical theological ecclesiology the approach was the evangelical model: how 'to church' the people and how to convert non-believers to God. Ministerial praxis was more or less evangelism. At the theology faculty we had a discipline called 'evangelistiek'.

12.Christian orthodoxy is based on God-images from which most traces of tenderness have been expunged. Pittinger (in Hall 1993:54) argued that the typical picture of divine omnipotence is a case of 'giving to God that which belongs exclusively to Caesar'. Even the love of God became a masculine affair supported by patriarchalism.

13.The 'popes' of synods dictated politics at the time. If it is true that different races and the variety of cultures is the will of God, 'apartheid' should be the solution to the possible tension and differences between races. If it is indeed the case that women are inferior to men, patriarchic thinking should be justified by theology in order to keep women from church decision-making and official functioning. 
God's truth in all dimensions of life: in the office, church, Christian life, world and society.

- The interactive approach focuses on an interdisciplinary approach trying to link the insights of theology to empirical insights emanating from an empirical epistemology designed by the secular human sciences. The focus shifted to the inductive method of research. The correlative approach viewed practical theology as communicationand action-oriented (Mette 1978:345). Within faculties that were more oriented towards religious studies, the spiral model in epistemology became fashionable. The use of the theory-practice-theory spiral leads for example to the following conclusion by Heyns and Pieterse (1990:48): practical theology may, because of its involvement with praxis, be described as empirical theology. With reference to the upcoming influence of the human sciences and sociological methods of research, the paradigm in theory formation within the South African Society for Practical Theology shifted at the end of the eighties from service to the Word (diaconology) to action of the believer. Practical theology became an action science, (referred to as handelingswetenskap in Afrikaans) $)^{14}$, with the focal point on theories of communication ${ }^{15}$. It was argued that practical theology, by becoming more empirical would be more practical, relevant and contextual ${ }^{16}$.

- The contextual approach seeks a link with the social situation and aims at generating transformation or liberation by means of a situation analyses. Otto (1975:11) pointed out that traditional practical theology suffered from a 'loss of reality' arising from the church's lack of involvement with social praxis. He argued that practical theology should be a critical theory about the mediation of religious issues with society (Otto 1975:23). According to McCann and Strain (1985:209) the focus of practical theology now becomes the transformation of the political and social environment ${ }^{17}$.

Given the three general approaches, I want to research a fourth possible approach: the hermeneutical and theoontological approach, for example, the question regarding the character of the praxis of God. The latter refers to the relevance of the 'how of God' (being function) within the context of human vulnerability (suffering and death). The first question to be addressed is the question regarding the normative and directing paradigms within these approaches and their impact on theory formation.

14.See Pieterse (1988:85-94) in his design for theory formation in homiletics; even the congregation should be assessed from the perspective of communication ( $p p$. $85,92)$.

15.See the emphasis on 'dialogiese kommunikasieteorie', (Vos \& Pieterse 1997:13, 19). In this regard Habermas's theory of communication became influential. See the emphasis on human actions and the understanding of what is meant by 'practical' (Van der Ven 1990:40).

16.According to Van der Ven (1993:15) due to the notion of religious communication, a contextual approach should view the church as a sociological phenomenon.

17.This model was not in the foreground of practical theological reflection in the South African Society due to a very exclusive approach in membership. It was mostly members of the three reformed churches from the Afrikaans speaking communities that ran the Society. Members did not represent communities involved in the struggle and the fight for political liberation.

\section{Paradigmatic changes in practical theological theory formation and problem identification}

In 1983 Don Browning identified the following paradigmatic shifts that took place in theory formation for practical theological reflection (1983:9f):

- The shift from the ecclesial or official paradigm, to a type of phenomenological ecclesiology. Practical theology is no longer about the internal life of the church, but rather about the public image of the church in the world.

- Practical theology is less about the content of faith and attained a more critical function within contemporary society. It should test the applicability of faith within the debate with other religions and secular spiritual images in a pluralistic society. Practical theology should focus on critical dialogue in an attempt to transform society.

- Practical theology should become public ethics. It is the task of practical theology to develop ethical norms for social and individual transformation. The focus is not so much on dispositional ethics, particularly, virtue and personal character, but on principle ethics engaged in individual and social transformation (Browning 1983:6).

- A shift away from theoretical principles towards a practiceoriented theory. Practical theology now establishes its theory by means of reflecting critically on the events in practice. "The difference between practice and praxis is that in the latter the theory has been made self-conscious and reflected upon critically' (Browning 1983:13).

- The greater role of the social sciences in a practical theological methodology. There is a need for an interdisciplinary approach. It is argued that the social sciences can of use because they can indicate which approach should be used for active intervention in practice.

- Practical theology is becoming more of a liberation theology. In the light of Neo-Marxist theories, practical theology is viewed as action focusing on political liberation. The shift is from speaking or verbalising (word) in the direction of doing (action).

The following critical question should be posed: what is the implication of these paradigm shifts ${ }^{18}$ for praxis thinking in theory formation for practical theology in South Africa?

It will be argued that, in order to comply with hermeneuticaland networking thinking, practical theology should rethink its theological foundation. If networking thinking and systemic thinking is becoming the dominant philosophical paradigm in globalisation, the quest for differentiation and

18.It is becoming clear, that in the light of fundamental paradigm shifts, models for theory formation in practical theology have changed dramatically. For example, the expansion paradigm (how many?) made place for the identity paradigm (the basis and foundation of one's claim); the imperialistic paradigm (authority as force and power) for the functional and pragmatic paradigm (how?, transformation and change); the metaphysical paradigm (what is beyond and the cause?), for the networking and relational paradigm (the quality of human life and the connection networking and relational paradigm (the quality of human life and the connection between different entities of life); the denominational paradigm (powerful big enterprises: the management of the 'church-company') for the intimate paradigm group-thinking and the quality of interconnectedness); the individualistic selfculture paradigm (personal need-satisfaction) for the sense-of-belonging paradigm (systems-thinking); the achievement paradigm (results, outcome and production) for the meaning paradigm (significance and purpose); the verification paradigm for the hermeneutical paradigm. 
identity ${ }^{19}$ becomes extremely important. In this respect even ontological thinking ${ }^{20}$ with its emphasis on essence and being becomes most relevant. It forces theology and very specifically practical theology to pose anew the question regarding the unique identity of practical theology and its understanding of the praxis of God.

The basic hypothesis of the article is that theopaschitic thinking can help practical theological thinking to reformulate the notion of 'theology' in praxis thinking. In order to reformulate or even to reconstruct theory formation in practical theology, the assumption is that 'being' qualities should not be formulated in terms of metaphysical substantial thinking but in terms of ontological passion thinking. In this regard Browning (1983:13) refers to David Tracy who believes that practical theology primarily has to do with the criteria or norms for the transformation of human brokenness (the praxis reality of our being human). Our human suffering and the quest for meaning determine all forms of praxis thinking. Theological praxis should be framed by the passion of God and not in the first place by the immutable and rational 'Council of God', (positivism of the Mind; the omniscience of the immutable Raad van God).

Praxis as a theological construct entails more than merely the functional paradigm of communicative human actions. As a theological category it is essentially an eschatological paradigm $^{21}$. Praxis thinking as a theological endeavour is inevitable passion thinking; it describes an ontological mode of com-passionate 'being-with'. Passion thinking leads to thecourage to be, that what one can call 'the fortigenetics of parrhesia'. 'Parrhesia' emanates from God's eschatological praxis of suffering (theopaschitism) as exhibited in the acts of cross and resurrection

\section{The praxis of God}

\section{Verified by observation and empirical experience or by hermeneutics and passionate being-with?}

In his reflection on empirical theology, the attempt of Hans Van der Ven (1990) ${ }^{22}$ was to design an empirical approach to theory formation in practical theology. The following important practical theological question surfaces: what is meant by the theological dimension

19.The notion of differentiation and identity within an interdisciplinary approach, poses anew the question: what is unique in practical theology if it wants to maintain its theological identity within the networking with psychology, sociology, politics and economics?

20.Ontology is used in terms of essential meaning, identity and a mode of being within the network of interactive relationships. Ontology differentiates one entity from another in terms of its essential characteristics and being-functions.

21.For the relationship between faith and eschatological thinking, see Hall (1993:94) 'For precisely as a category of relationship faith is also an eschatological concept: that is, it describes a state of hope that anticipates consummation but is perennially denied it as an accomplished reality'.

22.Der empirische Ansatz ist auf das Beschreiben und Erklären der hermeneutischkommunikativen Praxis ...', Van der Ven (1990:89). The emphasis in an empirical approach for the study of praxis are the experiences of faith: .... des Glaubensinnes und der Glaubenserfahrung' (1990:127). In der empirischen Forschung innerhalb der Theologie wird nicht der gläubige Mensch, sondern Glaubenskennzeichen gläubiger Menschen untersucht' (1990:129). implied in the empirical dimension of the praxis ${ }^{23}$ of practical theology?

It was the practical theologian, Friedrich Schleiermacher, who brought about a radical change in the paradigms of theological and practical reflection, and theory formation. He shifted the paradigms of practical theology from the hierarchical and clerical paradigm to the empirical dimension of human experience and religious experiences. Practical theology deals with 'applied' Christianity and is in this sense 'technical', for example, the development of skills and strategies for ministry (which he calls an art).

Burkhart (1983:56) argues that for Schleiermacher practical theology is the art of overcoming the distance between human life and what it is meant to be. In terms of recent developments, practical theology is viewed as an action science (Handlungswissenschaft) trying to connect the Christian faith to the praxis and context of our modern or postmodern society (Heitink 1993:18) ${ }^{24}$. Communication and the empirical dimension of human actions (from the perspective of their experience of God) have become an important paradigm for practical theological reflection (Van der Ven 1990:139). ${ }^{25}$

Several authors have emphasised the importance of the realm of action within practical theological reflection in the past twenty years. Osmer and Schweitzer (2003:1) refer to this dimension as 'action-guiding theories of contemporary religious practice'. Contemporary practical theology is therefore viewed as carrying out distinguishable but mutually influential tasks: the descriptive-empirical (What is going on?); the interpretive (Why is this going on?); the normative (The construction of theological and ethical norms by which to critically assess, guide and reform some dimensions of religious praxis; what forms ought religious praxis take in this particular social context?); and the pragmatic (Rules of art as open-ended guidelines for a specific religious praxis: how might this area of praxis be shaped to embody more fully the normative commitments of a religious tradition in this particular context of experience).

I would like to add a fourth task, an ontological task, for example, practical theological reflection on the 'how' of

23.For Aristotle, praxis is guided by a moral disposition namely to act truly and rightly (habitus); furthermore, praxis refers to a concern to further human well being and the good life. This is what the Greeks called phronesis [practical wisdom]. Praxis embodies a kind of wisdom thinking which is focused on an understanding of other people. Practical wisdom involves moving between the particular and the general. people. Practical wisdom involves moving between the particular and the general. We can now see the full quality of praxis. It is not simply action based on reflection It is action that embodies certain qualities. These include a commitment to human well being and the search for truth, and respect for others. It is the action of peopl who are free, who are able to act for themselves. Moreover, praxis is always risky. It requires that a person 'makes a wise and prudent practical judgment about how to act in this situation'. We can say that word and action, action and reflection, theory and practice are all facets of the same idea. This action is not merely the doing of something, what Freire describes as activism and Aristotle as poiesis. Poiesis (the creative dimension within actions; to bring about something good or beautiful) is about acting upon, doing to: it is about working with objects. Praxis, however, is creative: it is other-seeking and dialogic (Smith 1999).

24.In his book Praktische Theologie (1993:18) Heitink defines practical theology as 'handelingswetenschap'. He explains '... hier wordt verstaan de empirischegeorienteerde theologische theorie van de bemiddeling van het christelijk geloof in de praxis van het moderne samenleving'. 'Het gaat in de praktische theologie dus om het handelen Gods door de dienst van mensen' (1993:19)

25.Ganzevoort (2002:39) sees the human praxis of faith as the first order of reflection 'It is the experiences and constructions of individuals and communities, responding to what they perceive, construct as coming from God, and their discourse about God and towards God.' 
God's praxis (the being functions of God) operating within different modes of communication and action. This task is in terms of the philosophical dimension in praxis thinking, an ontological task. Part and parcel of this task is what De Gruchy (2001:3-34) calls the dimension of transformative aesthetics, for example, our ability to transcend the visible through imagination. Browning (1991:105) calls this the 'visional' dimension of practical moral thinking.

\section{Normative thinking in practical theology}

Besides the aesthetic dimension in practical theology, human actions are indeed embedded in norms and values. Ethical issues are at stake in the reflection on the praxis of human actions. According to Van der Ven (2002:23), it is therefore a false dilemma to juxtapose an empirical approach and a normative approach, and to separate them in theory formation. Without any doubt the empirical dimension of practical theology includes a normative dimension. In Habermas' terms ${ }^{26}$ (Van der Ven 2002:21), three normative questions should be posed in practical theology:

- The first is the teleological question relating to our personal and communitarian life: who are we, what do we consider good, what do we strive for, what do we value?

- The second is a deontological question relating to our responsibility to each and everybody and to humankind as a whole: what is just, what is right, what are our obligations?

- The third question is pragmatic or 'utilistic', relating to effectiveness and efficiency ${ }^{27}$ : which action will produce the intended result?

To my mind normative questions ${ }^{28}$ should include the foundational question: what is theological in the praxis of practical theological reflection? According to Jonker (1983:15) praxis and theory are inseparable: theology without praxis is empty and vague, praxis without theology is blind ${ }^{29}$.

It is understandable that in praxis thinking, besides a normative dimension, a structural approach ${ }^{30}$ is inevitable,

26.On the implication of Habermas' perspectives on practical theology and theory formation, see De Roest (1998); on the normative perspectives of practical theology see pages $269-353$.

27.On the praxis of the church, see Van der Ven (1993:12-13).

28.Normative questions refer inter alia to the hermeneutical and communicative praxis of faith. Immink (2003:19) calls this the religious praxis from the perspective of faith a praxis of faith which includes the praxis of the church (ministry). Van der Ven refers to a more functional and contextual ecclesiology which one can call a practical, theological ecclesiology.

29.'Nothing is as practical as good theory' Firet (1977:16).

30.'Practical theology occupies itself with the diaconic forms of churchly praxis (the division of "vertical" subjects) and more precisely with the church's functioning of role-fulfilment in those forms (the horizontal cross-section of these subjects)' (Fire 1977:22). The major contribution of Firet to practical theological thinking was that he wanted to link the normative question to Biblical thinking. His intention was to merge the notion of the praxis of the church with the categories of communication and action. In his attempt to design a theological approach to theory formation in practical theology, his emphasis was on the pastoral role-fulfilment as the action practical theology, his emphasis was on the pastoral role-fulfilment as the action of God who, by way of the official ministry as intermediary, comes to people in his word (Firet 1977:24). He still argued at that time within the current ecclesia paradigm of reformed thinking. Practical theology is praxeology; the systematic study of the vital manifestations and ministries of the church (Firet 1977, n. 23, 12). In his preface to the 1977 edition he gave the following clarification, "I no longe speak of "churchly functioning" and "pastoral role-fulfilment" but of practical theological communication and structures' (1977:7). but what is theological in these structures or several modes of communication?

In a practical theological ecclesiology several ministerial functions can be identified. They can be called normative modes of praxis-theology. They describe the different fields and modes of communication in theory formation with regard to a practical-theological ecclesiology:

- The mode of kerygma [preaching], the subject and field of homiletics in practical theology.

- The mode of catechetics and didache: [teaching of knowledge related to the confession and tradition of systematic reflection] conveying knowledge about the revelation of God in our history of salvation through Scripture and the confessional tradition of the church, the didactic dimension.

- The mode of paraclesis: [comfort, consolation] God's care and comfort for people (pastoral care) and the impact of God images on faith behaviour and processes regarding the 'ensoulment' of human life.

- The mode of koinonia [fellowship]: sharing and the interaction of believers; mutual care.

- The mode of oikodomein [edification and upbuilding of the church]: church growth and church development, church ministry.

- The mode of marturia [witness]: the missional outreach to the world.

- The mode of leiturgia [praise and worship]: the liturgy of the church.

- The mode of diakonia [service, reaching out the need of others] the sacrificial service of the church in the world and within different social and cultural communities (community development).

In considering the way in which different modes of praxis being are related to the field of practical theology, the following practical theological principles (as related to the praxis of understanding and/or interpretation, communication and/ or verbalising, acting, hoping, imagining and seeing) are at stake and can be most helpful and illuminating:

- Praxis thinking is that theological and academic professional field within practical theology that tries to describe and identify appropriate rational categories of understanding the comfort and compassion of God in order to portray meaningful images of God within the realm of human suffering and pain. This is described in the tradition of the church by the Latin term 'fides quaerens intellectum'.

- Praxis thinking represents the procedures and skills that try to communicate and verbalise the meaning dimension and the comfort of the praxis of God in such a way that people will be renewed and consoled: fides quaerens verbum [faith seeking different pathways of verbalising and communicating].

- Praxis thinking is about the 'enfleshment' and embodiment of the engagement of God with life issues in such a way that concrete actions of comfort, change, liberation and transformation take place as an expression of the vivid and 
actual presence of God: fides quaerens actum [faith seeking concrete expression by doing and different actions]. Note that the dimension of action immediately emphasises the importance of ethics in pastoral care.

- Praxis thinking fosters hope and instils anticipatory experiences of eschatology in such a way that our being functions are comforted. Comfort in this regard implies being empowered in one's being functions and discovering significance and meaning in such a way that the result is courage to hopeful being: fides quaerens spem [faith seeking different modes of hope, anticipating something new in the future].

- Praxis thinking inspires people for the 'ensoulment' of life by stimulating creativity and imagination in such a way that human souls can be illuminated and opened up for the aesthetic dimension of life through symbol, metaphor and liturgical rituals; faith seeking beauty ${ }^{31}$, aesthetic and creative expression of the content of faith: fides quaerens imaginem [faith expressed in different modes of creativity and aesthetic imagination]. Imagination and creativity represent the dimension of aesthetics in pastoral comfort: the healing that emanates from God's grace and salvation. ${ }^{32}$

- Praxis thinking opens the eyes of people (viewers) to traces of God's presence (seeing the unseen) in life through the spiritual dimension incorporated within drama, storytelling, narratives, symbols, metaphors and virtual reality. In this regard modern technology, the internet and the mass media become instruments in the portrayal of the truths of the gospel; faith seeking visual presentation and symbolic portrayal that can comfort: fides quaerens visum [faith seeking vision].

To conclude the argument thus far: The presupposition and basic assertion is that practical theology is that field within theology that deals with the praxis of God, in other words the implications of the God-human encounter for life and the human quest for meaning. Practical theology includes both ethics and aesthetics. It is interested in the intention, motivation and telos [purposeful meaning] of human actions within the field of ministry, communities of faith and social contexts. In this regard it tries to link appropriate understandings of God with the pastoral and hermeneutical endeavour of understanding the salvific actions of God and his presence in life events (intellectum). Furthermore, it is about the communication and proclamation of the gospel (verbum); the transformation and liberation of social contexts (actum); the fostering of a vivid hope within the realm of

31.The concept of beauty is related to the struggle to come to terms with the attemp of humankind to transcend all earthly boundaries and limitations. To be connected to the sublime by means of beauty is part of spiritual healing. Sublime is a quality possessed by a work of art which, as a result of the intention and inspiration rather than reasoned judgement, does not so much convince the viewer as it thrills or transports him (Couvée 2005:83). Aesthetics can be related to what is called 'das Erhabene' in German. The sublime also represents the dimension of light and mystery. Good examples are the Russian words vozvyshennoe [elevated, lofty], vysokoe [high, elevated], velichestvennoe [magnificence, grandeur], vostorg [rapture] and voskhishenie [ecstasy, delight] (Couvée 2005:86).

32.This consoling dimension can be related directly to the realm of the sublime in spirituality. 'Sublime' is the French translation of the Greek peri hupsous, which literally means 'about the elevated' (Couvée 2005:83). The concept of beauty in practical theology and pastoral care refers to the dimension of healing and in practical theology and pastoral care refers to the dimension of healing and the expression of meaning in life in such a way that instils hope. suffering (spem); the symbolic and metaphorical expression of the Christian faith through imagination, creativity and ritual (imaginem); and the portrayal of Christian spirituality through visual images, audio sounds and narratives that contain meaning and represent the 'seeing of the unseen' within virtual reality (visum).

The previous hermeneutical clarification of praxis thinking brings us back to the basic theological question in practical theological theory formation: what is the under girding Godimage operating within the praxis of God as well as within these epistemological conceptualisations of intellectum, verbum, actum, spem, imaginem and visum [understanding, verbalising, acting, hoping, imagining and envisioning] as related to the content of the Christian faith ${ }^{33}$

The operating presupposition is that spirituality in the Christian faith is inevitably related to our human suffering and vulnerability. The praxis of God is framed by the realm of suffering ${ }^{34}$.

Practical theological teleology is only possible when the practical concepts of praxis, encounter, ministry and communication are determined by the theopaschitic action of God: the passio Dei [passion of the suffering God]. Only then can practical theology claim that it is promoting change as hope: fides quaerens spem [faith expressed in the mode of hoping and anticipating a new future].

Such a theological endeavour implies that practical theology should re-assess existing categories used in theory formation.

\section{Towards a qualitative approach in theory formation \\ From zombie categories to passion categories (disciplinary differentiation)}

In his book Reconstructing Practical Theology. The Impact of Globalization, Reader (2008:1) warns against the danger of 'zombie categories' (Ulrich Beck), for example, the continued employment of concepts that no longer do justice to the world we experience and yet which are difficult to abandon because of tradition and also because they are not yet totally redundant. Zombie categories are therefore described as the 'living dead', the tried and familiar frameworks of interpretation that have served us well for many years and continue to haunt our thoughts and analyses, even though they are embedded in a world that is passing away before our eyes.

33.'De praktische theologie richt zich op het gebeuren tussen God en mens, mens en God en tussen de mensen onderling' (Jonker 1983:15)

34.The praxis of God then cannot avoid its intimate connectedness to the events of the Passover and the cross and resurrection of Christ as a revelatory exposure of the intentions of Gods actions (the core question in praxis thinking). This is what what Douglas Hall (1995:147) cals the 'profession of falth' profession is not to wemonstrate thall (encounter as analogia relationis [analogy of For Jerulasem being is pathos [compassion]. For the tradition of Jerusalem, being means the interrelatedness (ontological networking) of all that is. For Jerusalem being means being-with (Hall 1993:321) 
To my mind, two zombie categories in theory formation can be identified.

\section{Zombie category A}

Praxis as clerical maintenance of the official church (ministerial dimension): Reader aptly points out that the field of practical theology was for many years dominated by the clerical and official paradigm. As already discussed, this was the overarching category for theory formation in practical theology during the sixties and seventies. It dominated the Society for Practical Theology in South Africa when the reformed faculties of theology were the main role players. It became a zombie category due to the danger of praxis thinking as ecclesial and clerical self-maintenance. Praxis thinking cannot avoid the ecclesiological implications of ministry. However it should move from the exclusive category of the praxis of the official church into the vivid realm of communities, the public enterprise, of life itself. The networking of life should become the focal point of cura vitae [spiritual healing] (Louw 2008).

\section{Zombie category B}

Praxis as phenomenological observation of the experiences of faith (empirical dimension): On the other hand practical and pastoral theology has been overtaken by theory formation from the fields of psychology and sources of therapeutic knowledge, framed by the empirical methodology of the human sciences. Phenomenology and the qualitative and quantitative interpretation of the religious or faith experiences by means of observation and inductive methods of research became fashionable in order to adhere to the claim: practical theology is only a scientific endeavour when it adheres to empirical research methodology.

It cannot be denied that the qualitative method of research brought about a Copernican paradigm shift that cannot be ignored by practical theology.

Swinton and Mowat emphasise the value of qualitative research in their publication Practical theology and Qualitative Research (2006).

However, even a qualitative approach can become a zombie category due to the danger of praxis-thinking as merely a phenomenology of sociological and psychological practices. Is a qualitative approach merely the phenomenology of empiricism and experiential observation excluding the unique theological character of an epistemology of revelation?

Some proponents of qualitative research argue that reality in itself is inaccessible and that constructivism is all that there is (Denzin 1997). Constructivism, for example, the assumption that truth and knowledge and therefore all forms of human perception are constructed by individuals and communities, could become an exclusive approach when, in epistemology, it excludes other sources of knowledge derived from revelation.
It is my contention that praxis thinking in theory formation for practical theology cannot avoid the hermeneutical spiral between Biblical text and context. Due to the methodology of hermeneutics, praxis thinking, takes place within an interpretative paradigm dealing with the qualitative meaning of texts and human actions. In this regard qualitative research is an important ingredient of practical theological research and a practical theological epistemology.

With this epistemological framework in mind, it becomes clear why it is that within qualitative research the quest is not for objectivity and explanation (as per the natural sciences), but for meaning and a deeper understanding of situations.

(Swinton \& Mowat 2006:37)

Meaning is then a kind of 'narrated map of reality' which individuals, communities and cultures use to interpret their experiences.

It could be further argued that actions are the carriers of these maps of reality. It is therefore critical in practical-theological thinking to understand the meaning of action as enfleshed in habitus. Intentionality and teleology are fundamental to a qualitative approach, because it probes into the reason behind the ways individuals and communities act in the particular ways they do (the phronesis of praxis):

The quest for this type of understanding forms the heart of qualitative research and is a fundamental dimension of practical theology's endeavour to critically reflect on the nature of situations.

(Swinton \& Mowat 2006:38)

However the point is that if epistemology in practical theology implies not nomothetic truth (truth that must be falsifiable, replicable and generalisable) (Swinton \& Mowat 2006:40-41), but ideographic knowledge (ideographic knowledge presumes that meaningful knowledge can be discovered in unique, non-replicable experiences) ${ }^{35}$, what about revelatory truth as determined by pneumatology?

What should be asked here is whether this interpretative task of practical theology stays only close to experience (even experiences of God) (Swinton \& Mowat 2006:30)? ${ }^{36}$

Is it indeed true that the aim of practical theology is only to enable personal and communal phronesis; a form of practical wisdom which combines theory and practice in the praxis of individuals and communities? (Swinton \& Mowat 2006:26). But what about the theological phronesis implied by the 'praxis of God' and as narrated in Scripture? What about the belief system and theological paradigm derived from Scripture that function as a normative entity and motivational actor

35.Swinton and Mowat (2006:43) argue that ideographic truth is important from the perspective of practical theology because it is integral to the language of scripture and tradition. 'God reveals God's self in and through knowledge that is profoundly ideographic. The major events of the Christian narrative- incarnation cross, resurrection - are clearly ideographic knowledge. Ideographic knowledge is also an integral part of the experiences and situations that practical theology is also an integral part of the experiences and situations that practical theology knowledge is very important for the practice of Practical Theology.'

36 .'While concerned with theory as a necessary aspect of practice, it is not focused on the development of comprehensive, theological systems which understand
themselves as concerned with the development of forms of knowledge extrapolated from any form of practice' (Swinton \& Mowat 2006:26). 
within the praxis of the church ${ }^{37}$ ? When Swinton \& Mowat (2006:21) refer to the fact that with Christian practice they have something normative and theological in mind, what is the character of this normative and theological cause?

In order to enhance the theological discussion in practical theory formation, I want to propose two possible dimensions for analysing 'reconstructing categories' regarding a practical theological theory. They are the dimension of an ontological hermeneutics and the philosophical dimension of wisdom thinking (sapientia).

\section{Reconstructing category A}

The ontological dimension of a praxis-hermeneutics (being thinking) and the interpretation of the praxis of God: According to Reader (2008:6) the 'hermeneutical model of pastoral engagement' surfaced and is putting new challenges before practical and pastoral theological reflection, for example the question regarding the theological foundation of praxis-thinking and its implication for being and the quest for meaning.

The 'monogamy of space' of the earlier modern age has been transformed into the 'polygamy of space', whilst the categories 'rural' and 'urban' made place for the categories of 'local' (integration) and 'global' (fragmentation) (Reader 2008:11). The categories of 'explanation' and 'verification' made place for 'networking' and 'interpretation'. Instead of the question: what is the cause behind life events, the question should become: what is the meaning within the events of life? What is the significance or purposefulness of life and the destiny of being? The basic assumption is: the praxis of God within the realm of suffering

\section{Transcendent category B}

The philosophical dimension of practical reason and the quest for the 'spirit' of wisdom and meaning: In his book Religion before Dogma McCaughey (2006:240-242) points out the importance of understanding 'practical' not in the sense of pragmatics but in the Kantian sense of practical reason. In his plea for practical theology as 'relational theology' he refers to the fact that our experience and consciousness is determined by conceptual structures. A conceptual structure contains 'ideas' about experience and behaviour and operates as a regulative a priori for human behaviour. He calls them 'synthetic judgments'. They constitute a set of a priori transcendental ideas that we must assume. 'Spirit' is therefore an ingredient of human action and behaviour. Transcendental ideas function as a kind of spiritual realm within the dynamics of relational networking. 'Among these transcendental ideas are what we mean by God, freedom, and the self' (McCaughy 2006:vii). In this regard practical theological theory formation should be an endeavour of the

37.It is indeed a practical theological question how to link, in a qualitative and hermeneutical approach, the praxis of actions of faith with the actions and praxis of $\mathrm{God}$ : the pneumacis of God. the pneumatological dynamics within phronesis. Praxis as a theological of swinton and we defor We defined Practical Theology as critical, theological reflection on the practices of the Church as they interact with the practices of the world with a view to ensuring faithful participation in the continuing mission of the triune God.' spirit of God and therefore fundamentally a pneumatological endeavour.

Transcendental ideas accompany all experience as a priori to appearances of phenomena. It is therefore the task of practical theology to shed light on these 'paradoxical necessities' (our experience of should). The implication of McGaughey's approach is that practical theology becomes involved in the creative constructions of the human mind (spirit): creative vision. Practical theology is therefore interested in deontology and the intentional realm of human actions. Practical theology is relational teleology, not merely pragmatics. In this regard an understanding of the philosophical dimension ${ }^{38}$ of human experiences and actions, and its link with existing God-images is fundamental to a practical theological hermeneutics.

The philosophical dimension of practical theology can be linked to the tradition of wisdom thinking (sapientia [wisdom of the heart] as supplementary to scientia [rational and analytical knowledge]). The philosophical dimension of practical reason reveals belief systems and their influence on behaviour, actions and being.

D.S. Browning (1991:9-10) refers to practical reason as a fundamental feature of practical theology. Practical reasoning is embedded in patterns of thinking as expressions of human ideas and concepts, in other words, paradigmatic frameworks of the human mind as connected to belief systems. Browning confirms that these frameworks are reasonable and rational representations of convictions and philosophies of life. They are shaped by cultural contexts, expressed in metaphors, portrayed by symbols, and 'enfleshed' in habitus [attitude as a being function].

Within the context of the Christian faith, habitus [attitude as a being function] is the carrier and container of phronesis [practical wisdom]. Habitus reflects meaning and spirit. Meaning-identification (also referred to as Sinduiding in Afrikaans and, Sinndeutung in German) should be identified as a fundamental endeavour of practical theology. ${ }^{39}$ Meaning as a fundamental ingredient within the praxis of practical theology, should be understand as a pneumatological event, that is as an action derived from the pneumatological dynamics of the praxis of God (The eschatological event of salvation and the sanctification of life through the fruits or charisma of the Spirit).

38.The philosophical dimension of life events is acknowledged in a fairly new development in care and counseling, namely 'philosophical counseling'. Its aim is to help you apply the narrow insights you learn about yourself to the big picture of your life; 'to integrate every conceivable insight (psychological insights being just one kind) into a coherent, workable outlook on and approach to life' (Marinof 1999:30-31). It is therefore the contention of Marinoff that if the root of your problem is philosophical, nothing on your pharmacist's shelves is going to give lasting relief. 'Drugs don't do anything in the outside world - even with a mood softened by Prozac, you'll still have to deal with a sadistic boss or a cheating partner or a bureaucratic bank' (1999:33-34).

39.See in this regard the conviction of the practical theologian Gräb (2000:42) that practical theology as a hermeneutical endeavour should be engaged in the act of meaning identification within the realm of life; , sinnorientierendes Lebensdeutung'. Even the articulation of the concept 'God' cannot be done without the quest for meaning Gräb (2006:30). His argument is that a normative-deductive approach is inappropriate within a secularised society. Thus his option for what he calls a is inappropriate within a secularised society. Thus his option for what he calls a
,phamenologische und kulturhermeneutische Ausrichtung der Praktischen Theologie' (2002:41). 
Ed Farley (1983:21-41) in the publication on theory-formation in practical theology argues that theologia practica is simply the habitus [attitude as being function] viewed as to its end (from the spiritual perspective of the ultimate):

Practice meant that aspect of habitus, or wisdom, in which the divine object sets requirements of obedience and life. Both reside in the single existential habitus called theology. Theory/practice is based here on what could be called a 'phenomenology of theology as habitus'.

(Farley 1983:27)

Practical reasoning implies wisdom thinking (Schipani 2003). As an existential category habitus then should refer to an ontic state: the mode of being.

In his book on theory formation for practical theology, Osmer (2008:163) opts for a cross-disciplinary dialogue in a communicative model ${ }^{40}$ of rationality. In this model 'rationality' is viewed as a special form of communication in which people offer reasons to others in support of their assertions ${ }^{41}$. But how does it reflect habitus and the disposition of wisdom?

If one can accept that, in terms of the previous outline, practical reasoning implies wisdom thinking within a communicative model of rationality, the question of the link between praxis and the theological qualification of ministerial or diaconic praxis emerges; wisdom thinking within an ontological model of being and a hermeneutics of God's praxis.

\section{The divine ontology of bowel categories \\ Passion as praxis in practical theology}

Theuns Dreyer wrote an important book with the title Poimeniek (1981:11) ${ }^{42}$. He emphasised the importance of the shepherding perspective in pastoral care. The shepherd metaphor represented the concept of loving care and protection. Hiltner (1959) ${ }^{43}$ referred to the shepherding perspective and to the function of the Christian shepherd dimension of 'solicitous care'. The shepherding perspective within the South African Society for Practical theology during the seventies and eighties was dominated by the clerical ${ }^{44}$ and homiletic paradigm, not by the theopascitic paradigm.

It will now be argued that the praxis of God's ta splanchna can help theory formation and the shepherding perspective

40.See in this regard: Henk De Roest, Communicative Identity. Habermas' Perspectives of Discourse as a Support for Practical Theology (1998). See also Ganzevoort (2002:34-42).

41.Osmer (2008:114) underlines the necessity of a careful analyses and evaluation of theories: (1) the model or root metaphor, a theory uses and the conceptual field built on this model; (2) the disciplinary perspective a theory uses and the level of reality this discipline addresses; (3) the soundness and the strength of a theory's argument(s).

42.Poimenetics is a combination between poimanio [care] and techne [function]. The emphasis in care is therefore on the art of shepherding ('die kuns van herder wees' Dreyer [1981:14]). He sees shepherding as predominantly the mission of the church (p. 15).

43. For Hiltner (1959:28) the operating principle of shepherding involves concern and acceptance. However the clerical paradigm still dominates: shepherding in grief and loss is the function and prerogative of the pastor (1959:42).

44.Shepherding is an ecclesial function (De Klerk 1978:18). in practical theology to trace back the foundational roots of the praxis of shepherding. In terms of theopascitic thinking, shepherding refers to the 'bowel-category' of being-with.

\section{Ta splanchna The passio Dei in theopachitic theology}

In the effort to identify God with human suffering, theopaschitism became the theory or doctrine by which theology tried to construe a more passionate approach to our understanding of God's presence within the reality of human suffering (injustice, poverty, stigmatisation, discrimination, stereotyping, illness, violence, the abuse of power, tsunami's, catastrophes).

A theopaschitic approach, which leans strongly towards divine pathos, acceptance and understanding, has been welcomed by those theologians who wanted to reframe paradigms regarding God's praxis. In this regard the attempts of Sally McFague to construct a heuristic theology of deconstructing existing theistic models into a metaphoric theology wherein the whole of the cosmos is becoming a metaphor for the 'body of God'45. No longer is God seen as static and absolute, but dynamic, thereby opening up the future for human existence.

The value of theopaschitic thinking for the praxis of God is that it proposes a shift from the substantial approach to the relational and encounters paradigma (Berkhof 1979:32-33). The switch is then from the attempt of orthodoxy to uphold ecclesial triumphantilism (Hall 1993:100-101), a theology of glory (theologia gloriae) and an imperialistic ecclesiology of omnipotence (powerful force) ${ }^{46}$, to a theology of the cross (theologia crucis $)^{47}$ of weakness, suffering and passion.

It is my contention that the passio dei displays praxis of ta splanchna [strong feeling of mercy and compassion expressed by intestines]. The latter is related to the Hebrew root $r h m$ [to have compassion]. It is used in close connection to the root hnn [to be gracious]. Together with oiktirmos [compassion] and hesed [faithfulness as expressed in grace] it expresses the

45.In metaphorical theology the assumption is that all talk of God is indirect: 'No words or phrases refer directly to God, for God-language can refer only through the detour of a description that properly belongs elsewhere' (McFague 1987:34). A metaphor invites us to speak of God symbolically in terms of concepts well-known to us, in order to consider some qualities associated with a specific concept as a partial, but perhaps illuminating way of speaking of aspects regarding God's a partial, but perhaps illuminating way of speakith ' relation to us. However, a model is a metaphor with 'sayng power'. A model is metaphor that has gained sufficient stability and for relatively comprehensive and cohion ' (McFague 1987:34) Metaphorical theology could, therefore, best be described as 'heuristic', a way of finding out, discovering, in order to comprehend and interpret. 'This heuristic theology will be one that experiments and tests, that thinks in as-if fashion, that imagines possibilities that are novel, that dares to think differently' (1987:36) Inter alia, especially McFague (1987:33) strives towards such a new metaphorical theological concept. Because God is often conceptualised in the tradition of the church as King, Lord, Ruler and Patriarch, she proposes another metaphor. 'I will suggest God as mother (father), lover, and friend. If the world is imagined as selfexpressive of God, if it is a "sacrament" - the outward and visible presence or body of God .... Would not the metaphors of parents, lovers, and friends be suggestive, with their implications of creation, nurture, passionate concern, attraction, respect, support, cooperation, mutuality?' (1987:61-62).

46.See in this regard the remark of Hall (1993:108): 'Powerful people demand powerful deities - and get them!'; 'Power - and precisely power understood in the usual sense - is of the essence of divinity shaped by empire' (1993:107).

47.'Greek epistemology could not take account of the surprise needed to recognize God on the cross ...It did not envision suffering as a source of knowledge' (Sobrino 1993: n. 8, p. 105). 
'being' quality of God as connected to human vulnerability and suffering (Esser 1976:598). The verb 'splanchnizomai [emotional expression of compassion and sympathy]' is used to make the unbounded mercy of God visible.

Ta splanchna reveals God as a presence, 'a Companion, "your God"' (Hall 1993:147). In praxis thinking it is not the task of the church to demonstrate that God must be, but to bear witness to God's being-there, being-with, and being-for the creature. In terms of Hall (1993:155) the test of the church's God-talk at any point in time is it contextual authenticity, its praxis thinking: does it illuminate God's being-with-us?

In general the Greek term 'to splanchnon' refers to the valuable parts, the heart, lungs, liver, but also the spleen and the kidneys. During the sacrifice they are removed for the sacrificial meal. With reference to human beings splanchna refers to the human entrails, especially for the male sexual organs and the womb, as the site of the powers of conception and birth. Within metaphoric speech ta splanchna expresses pity, compassion and love. "The oldest form of the verb is "splanchneuo", eat the entrails, and prophesy from the entrails' (Esser 1976:599). Within the messianic context of Christ's salvific mission, ta splanchna expresses compassion as an indication of Gods divine involvement with the human predicament of suffering.

It is interesting to note the cases where Christ responded to human suffering with the contraction of the entrails, expressing messianic compassion. For example the leper with his petition (Mk 1:41), the people like sheep without a shepherd (Mk 6:34); Mt 9:36: the sight of the harassed and exhausted crowd; Mt 20:34: two blind men who besought him; Lk 7:13: the widow at Nain mourning her only son. In Luke 15:11-32, the prodigal son, splanchnizomai [emotional expression of compassion and sympathy] expresses the strongest feeling of a merciful and loving reaction (v. 20). In the parable of the good Samaritan (Lk 10:33) splanchnizomai expresses the attitude of complete willingness to use all means, time, strength, and life, for saving at the crucial moment (Esser 1976:600).

The point in these texts is that if it is true that praxis refers inter alia to intentionality and teleology, splanchnizomai reveals the very character of God within the messianic involvement and engagement with human suffering. The theology of the entrails reflects God's 'being' quality. It can be called an ontology of God's being within human suffering. Noteworthy in this regard is the fact that within these texts ta splanchna is connected to illness and health, dying and mourning, loss and grief, violence and injustice, burnt out and hunger, estrangement and remorse.

From a practical point of view the general and traditional theological question is always the cause-effect question: why God and weather God is behind these cases? From a praxis point of view the question is not whether God is behind these events but what is God's attitude and intention within these events? What is the mode of God's being within our human predicament? The texts totally reframe our understanding of who God is (mode of God) and what is meant by God's power. The latter now understood as passion and compassion, and not as an omnipotent force in the mode of a Ceasar-like power $^{48}$.

It is clear that suffering, as a theological issue, creates a tension: the tension between God's sovereignty (power) and his solidarity (pathos). An overemphasis of God's identification with suffering presents the danger that God's immanent experience is traded for his sovereignty. On the other hand, a theology that emphasises God's sovereignty and his punishment, thereby distancing God from suffering, incurs the danger of presenting God as alienated from reality. This antinomy brings us to the heart of the theodicy question.

In an inclusive approach to theodicy the attempt of theology was to emphasise the omnipotence and omniscience of God as the power over and control of suffering. The theopaschitic theology was a reaction over against this inclusive model, thus the attempt to link suffering to the passion of God and to argue that suffering is in this sense not the will of God (the exclusive approach).

According to theopascitism, God does not will evil, as such, but he himself even suffers in some way with, or under, evil in order to display his compassion (pathos). The cross of Christ becomes the proof that God is not unyielding and sadistic, but is deeply affected by evil. God identifies with suffering and is not apathetic towards it. In his sympathetic involvement with suffering, God shows his compassion, thereby proclaiming that suffering is directly opposed to his will.

Some of the most important proponents of theopaschitism are:

- God's weakness (Bonnhoeffer 1970): By his suffering, God shows that he is weak, vulnerable and powerless in this world. Only Christ's weakness can help us to resist suffering in an attitude of protest, resistance and surrender (Widerstand und Ergebung).

- God's powerlessness (Sölle 1973): In her book, Leiden, Sölle objects to the sadistic image of God evident in traditional theodicy. She portrays Christ as God's representative, who introduces himself as the one who suffers with humans.

Wherever people suffer, Christ suffers too. God suffers particularly in the social and political dimensions of suffering. God justifies himself in political suffering. He remains powerless and is dependent on us to bring about change. As

48.Inbody (1997:140) captures this problem very aptly when he argues that, in our attempt to rethink the meaning of divine power, two things can happen. Our Godimage can become 'too small,' or 'too big.' If God can only empathise with the suffering of the world, but can do nothing about it, God is too small. If God is suffering of the world, but can do nothing about it, God is too small. If God is identified with nature, and can do nothing more than what positivists mean by natural law, God is too small. If God is identified with human capacities, abilities, creativity or human ideals, then God is minimalised. On the other hand, if God is identified with omnipotent power, as the kind of power that, because of definition can do 'just anything', God is too big. When a theistic notion of divine omnipotence portrays God's kingdom in terms of an empire, he becomes too militant and strong. God is then merely a Hellenistic 'pantokrator [power as force and physical strength]'. 
Christ's representatives, it is thus our task to eliminate social and political suffering:

- God's being as an event of becoming (Gottes Sein ist im Werden) (Jüngel 1967): God's revelation of himself is not complete. This does not mean that God himself is incomplete, but rather that God reveals himself as a Fürsich-sein [a being-unto-himself] who, in his grace, is also a Für-uns-sein [a being-for-us]. In his capacity as a being for us God becomes involved in the suffering of humankind, and thus he becomes a suffering God for sinners in a dynamic act of revelation. In these events of God-beingfor-us God's being is still in the process of becoming (incomplete).

- God's forsakenness (Moltmann 1972): God's dynamic involvement in suffering is a Trinitarian event, the true character of which has been revealed by the cross. In the God-forsakenness of the cross (derelictio [forsakenness]), God is the Ganz Andere [totally other] who does not have to be justified by humankind. On the cross, God justifies himself as the one who pronounces justification on humankind. He does this by completely identifying himself with human suffering and displaying solidarity with human forsakenness.

- God's defencelessness (Berkhof 1973; Wiersinga 1972): Wiersinga rejects the notion that suffering is punishment for sin. For him, there is no likelihood of God's justice being punitive or retaliatory. He contends that it can be discounted that God is the origin of suffering, or that he wills suffering and has accommodated it in his providence. The only connection between God and suffering is that he himself suffers with us. Here God reveals himself as the defenceless God, in anticipation of the ultimate elimination of suffering. In the meantime, Christ's suffering not only brings about a change in people, but also effects change in the present reality; the ultimate goal being the termination of all suffering.

According to Berkhof (1973), God's defencelessness is the space that he has left for the freedom of human responsibility. Berkhof does not regard this defencelessness as mere powerlessness, but as a display of God's overwhelming love (power). God can withdraw because he knows that he will win. This withdrawal is the first visible aspect of a movement, which, in fact, is the opposite of withdrawal: it is a new, concealed, active or working presence which emerges in Christ's resurrection as a supreme presence against sin and death.

The theopaschitic approach clearly links God to suffering. The cross completes this link and reveals God as a 'pathetic' being: he is the 'suffering God.' Feitsma (1956) calls this form of theopaschitism (redefining God's being in terms of suffering) the most ultimate expression in theology of what is meant by God's compassion. ${ }^{49}$

49.'Maar als we de noemer aldus onder woorden brengen: natural divina passa est, dan moeten toch al die vormen op deze noemer gebracht worden' (Feitsma 1956:42). Cf. also Feitsma's observation on page 143: 'Ook in het modern theopaschitisme horen we steeds weer dat geluid van Gods eigen lijden. En da niet als een consequentie van communicatio idiomatum in de ene hypostase van Hem die God en mens is (wie langs deze weg komt tot het spreken over Gods lijden kan zich daaravoor op de Schrift beroepen), masr als typering van Gods diepste wezen.'

\section{Research finding and conclusion}

Ta splanchna describes the praxis of God's being not in substantial categories, but in terms of passion categories. The latter indicates how God essentially is towards human beings. In terms of bowel categories the Father in the parable of the prodigal son did not even know whether his son is coming back or not. His patience of waiting is not artificial make-belief or window-dressing, thus the reason for a deepseated existential anxiety and the turmoil of his intestines.

On an ontological level the implication is that bowel categories do not describe the immutability of an omnipotent 'Ceasar God' or the omniscience of a 'Computer God'. Bowel categories describe the ontological modus of a covenantal and faithful God. The intestines indicate God is in his very being the living God; the God of amazing grace and unconditional love. Even to the extent that, in terms of bowel categories, theology should shift from the zombie theological category of 'omniscience' (the all-knowing God of positivism and orthodoxy) to the reconstructing (McGaughey) theological category of passion (the not-knowing God of theopaschitism and orthopraxy). In this regard Browning's reference (1983:13) to David Tracy's conviction that practical theology has primarily to do with the criteria or norms for the transformation of human brokenness is addressed. Our human suffering and the quest for meaning determine all forms of praxis thinking. God's praxis in practical theology determines on a pneumatological level all forms of human action in suffering and vulnerability.

The under girding God-image operating within the praxis of a compassionate God, is God as our covenantal companion and friend for life. This praxis of God qualifies all epistemological conceptualisations and modes of a practical theological action: the modes of intellectum, verbum, actum, spem, imaginem and visum [understanding, action, communication, hope, imagination anad vision].

The ontological realm of the praxis of God should be described inter alia as ta splanchna [strong feeling of mercy and compassion expressed by the intestines]. In this regard the notion of 'bowel categories' describes a practical theology of the intestines. The intention and motivation within praxisactions is the passio Dei [compassion of the suffering God].

Practical theology as affirmation theology affirms our courage to be not in terms of positive thinking but in terms of positive being and hopeful living. Positive being and hopeful living are the outcome of eschatological thinking. Hope is not a cognitive, conative or affective category. Hope is an ontological category. It is an indication of our new status (being) in Christ.

The impact of our new status in Christ (eschatological status) on human identity is that eschatology affirms our very being as the courage to be and a passion to act. It describes the ontological praxis of what I want to call the 'fortigenetics of being': parrhesia. 
The notion of fortology represents a movement away from pathology to constructive enforcement and encouragement. Strümpfer, for example, points out the importance of fortigenesis in adult life (2006:11-36). Fortigenesis (fortis means strong) refers to a strengths perspective ${ }^{50}$, which relates human wellness to the positive components in human behaviour. This approach concentrates on those components in human wellness that create strength ${ }^{51}$, courage and a positive approach to life demands. Within the pneumatological praxis of passion-thinking spiritual strength refers to the charisma, fruit of the Spirit. Spiritual fortigenesis and fortology refer therefore to that kind of spiritual strength and courage that emanates from our new being in Christ determined by the praxis of God's passion.

The equivalent in Scripture for fotigenesis is parrhesia, a courage that is not a human quality but a quality that comes from God and Christ (I Th 2:2). Parrhesia is a pneumatic function as part of the fruit of the Spirit; parrhesia leads to hope as a new understanding of our renewed state of being (Louw 2008:223).

Within practical theological reasoning, parrhesia can be linked inter alia to the following praxis-verbs: understanding and/ or interpretation; communication and/or verbalising; acting; hoping; imagining, and seeing.

Ta splanchna describes the compassionate praxis of the crucified God. Practical theology is essentially practical when it changes our human brokenness into the healing of eschatological hope: fides quaerens spem [faith seeking different expressions of hope].

\section{Acknowledgements Competing interets}

The author declares that he has no financial or personal relationship(s) which may have inappropriately influenced him in writing this article.

\section{References}

Barnard, A.C., 1979, 'Die plek en betekenis van die kleingroep', in J.J. de Klerk (red.), Evangelistiek, N.G. Kerkboekhandel Transvaal, Pretoria.

Berkhof, H., 1973, Christelijk geloof, Callenbach, Nijkerk.

Berkhof, H., 1979, Christian Faith, Eerdmans, Grand Rapids, MI.

Bonhoeffer, D., 1970, Widerstand und Ergebung: Briefe und Aufzeichnungen aus der Haft, Kaiser, München.

Browning, D.S., 1991, A Fundamental Practical Theology, Fortress Press, Minneapolis, MN.

Burkhart, J.E., 1983, 'Schleimacher's Vision for Theology', in D.S. Browning (ed.), Practical Theology, pp. 42-60, Harper and Row, San Francisco, CA.

Burger, C.W., 1988, Die stand van die Praktiese Teologie in Suid-Afrika, Navorsingsverslag RGN, Stellenbosch.

50 .The background to a 'science of strength' is to be found in the meaning dimension of life. Interpersonal flourishing and subjective well-being are closely related to one another. Research applications in the field of positive organisational behaviour are developing as part of the paradigm of fortology. Both psychofortology and are developing as part of the paradigm of fortology. Both psychofortology and positive psychology support the development of human strengths and their role in motivation and constructive performance. In theological terms fortology and a strengths perspective are the equivalent of what is meant by the courage to be in
the language of existential theology.

51.The emphasis on strength is intended to encourage a move away from the paradigm of pathogenic thinking and to link health to a sense of coherence, personality hardness, inner potency, stamina or learned resourcefulness (Strümpher 1995:83).
Casteel, J.L., 1967, Spiritual Renewal through Personal Groups, 5th edn., Association Press, New York.

Castells, M., 2004, The Power of Identity. Volume II. The Information Age: Economy, Society and Culture, 2nd edn., Blackwell Publishing, Malden, MA.

Couvée, P., 2005, 'Aspects of Sublime and Istinnost in Contemporary Russian Poetry: The Mystic Sublime in the Poetry of Leonid Aronzon and Olga Sedakovs', in W. van den Bercken \& J. Sutton (eds.), Aesthetics as a Religious Factor in Eastern and Western Christianity, pp. 81-100, Peeters, Leuven.

Cox, H., 1967, The Secular City, SCM Press, London.

De Gruchy, J.W., 2001, Christianity, Art and Transformation: Theological Aesthetics in the Struggle for Justice, Cambridge University Press, Cambridge.

De Klerk, J.J., 1978, Herderkunde, NG Kerk-boekhandel, Pretoria.

De Klerk, J.J., 1979, 'Begripsbepaling', in J.J. de Klerk (red.) Evangelistiek, pp. 1-10, N.G. Kerkboekhandel Transvaal, Pretoria.

Denzin, N.K., 1997, Interpretive Ethnography: Ethnographic Practices for the $21^{\text {st }}$ Century, Sage, Thousands Oaks, CA.

De Roest, H., 1998, Communicative Identity: Habermas' Perspectives of Discourse as a Support for Practical Theology, Kok, Kampen.

Donga, H.C., 1989, Ontmoeting: Een studie over pastoraat en ontmoeting, Narratio, Hardinxveld.

Dreyer, T.F.J., 1981, Poimeniek: 'n Pastoral orientasie, HAUM, Pretoria.

Esser, H.-H., 1976, 'Splanchna', in C. Brown (ed.), Dictionary of New Testament Theology, vol. 2, Paternoster Press, Exeter.

Farley, E., 1983, 'Theology and practice outside the clerical paradigm', in D. Browning (ed.), Practical Theology, pp. 21-41 at 27, Harper \& Row, San Francisco, CA.

Feitsma, M., 1956, Het theopaschitisme: Een dogma-historische studie over de ontwikkeling van het theopaschitisch denken, Kok, Kampen.

Firet, J., 1977, Het agogisch moment in het pastoraal optreden, Kok, Kampen.

Ganzevoort, R.R., 2002, 'WYSIWYG. Social Construction in Practical Theological Epistemology' Journal of Empirical Theology 15(2), 34-42.

Girard, R.C., 1972, Brethren Hang Loose, Zondervan Publishing House, Grand Rapids, MI.

Gräb, W., 2000, Lebensgeshichten, Lebensentwürfe, Sinndeutung: Eine Praktische Theologie gelebter Religion, Gütersloher Verlagshaus, Gütersloh.

Gräb, W., 2002, Sinn furs Unendliche: Religion in der Mediengesellschaft, Chr. Kaiser/Gütersloher Verlagshaus, Gütersloh.

Gräb, W., 2006, Sinnfragen: Transformationen des religiösen in der modernen Kultur, Chr. Kaiser/Gütersloher Verlagshaus, Gütersloh.

Hall, D., 1993, Professing the Faith: Christian Theology in a North Americal Context, Fortress Press, Minneapolis, MN.

Heitink, G., 1993, Praktische theologie: Geschiedenis, theorie, handelingsvelden, Kok, Kampen.

Heyns, L.M. \& Pieterse, H.J.C., 1990, Eerste treë in die Praktiese Teologie, Gnosis, Pretoria.

Hiltner, S., 1959, The Christian Shepherd: Some Aspects of Pastoral Care, Abingdon, Nashville, TN.

Inbody, T., 1997, The Transforming God: An Interpretation of Suffering and Evil, Westminister John Knox Press, Louisville, KY.

Jonker, H., 1969, Leve de kerk, Callenbach, Nijkerk.

Jonker, H., 1983, Theologische praxis: problemen, peilingen en perspektieven bij kenterend getij, Callenbach, Nijkerk.

Jonker, W.D., 1981, In diens van die Woord, NG Kerkboekhandel, Pretoria.

Josuttis, M., 1980, Praxis des Evangeliums: Zwischen Politik und Religion Grundproblemen der Praktische Theologie, 2nd edn., Kaiser, München.

Jüngel, E., 1967, Gottes Sein ist im Werden, 2nd edn., JCB Mohr (Paul Siebeck), Tübingen.

Kiesow, E.-R., 1978, ,Die Seelsorge', in Handbuch der Praktischen Theologie, Band III. n.p.,Evangelische Verlaganstalt, Berlin.

Louw, D.J., 1980, Stad in die mens, N.G. Kerk Boekhandel Transvaal, Pretoria.

Louw, D.J., 2008, Cura Vitae: IIIness and the Healing of Life, Lux Verbi, Wellington.

Marinoff, L., 1999, Plato not Prozac! Applying Eternal Wisdom to Everyday Problems, Quill, New York.

McCann, D.P., Stain, C.R., 1985, Polity and Praxis: A Program for American Practical Theology, Winston, Mineapolis, MN.

McFague, S., 1987, Models of God, Fortress, Philadelphia, PA.

McGaughey, D.R., 2006, Religion before Dogma: Groundwork in Practical Theology, T\&T Clark, New York.

Moltmann, J., 1966, Theologie der Hoffnung: Untersuchungen zur Begründung und zu den Konsequenzen einer christlichen Eschatologie, 5th edn., Kaiser, München.

Moltmann, J., 1972, Der gekreuzigte Gott, Kaiser, München.

Moltmann, J., 1975, Kirche in der Kraft des Geistes: Ein Beitrag zur messianischen Ekklesiologie, Kaiser, München.

Mette, N., 1978, Theorie der Praxis, Patmos, Düsseldorf.

Osmer, R.R. \& Scweitzer, F., 2003, 'Introduction', in R.R Osmer \& F. Schweitzer (eds.), Developing a Public Faith: New Directions in Practical Theology, pp. 1-20, Chalice Press, St. Louis, MO. 
Osmer, R.R., 2008, Practical Theology: An Introduction, Eerdmans, Grand Rapids, MI. Otto, G., 1975, 'Praktische Theologie als kritische Theorie religiös vermittelte Praxis', in Praktisch Theologisch Handbuch, n.p., Furche, Hamburg.

Pieterse, H.J.C., 1981 Die daad by die woord: Christenwees in die tagtigs, N.G. Kerkboekhandel Transvaal, Pretoria.

Pieterse, H.J.C., 1988, Die woord in die werklikheid: 'n Teologie van die prediking, N.G. Kerkboekhandel, Pretoria.

Reader, J., 2008, Reconstructing Practical Theology: The Impact of Globalization, Ashgate, Aldershot.

Reid, C., 1969, Groups Alive - Church Alive, Harper \& Row, New York.

Robinson, J.A.T., 1963, Honest to God, SCM Press, London.

Schipani, D.S., 2003, The Way of Wisdom in Pastoral Counseling, Institute of Menonite Studies, Elkhardt.

Smith, K., 1999, Praxis, viewed n.d., from http:/www.infed.org/biblio/b-praxis.htm. Sölle, D., 1973, Leiden, Kreuz, Stuttgart.

Stollberg, D., 1971, Seelsorge durch die Gruppe, Vandenhoeck \& Ruprecht, Göttingen.
Strümpfer, D.J.W., 1995, "The origins of health and strength: from "salutogenesis" to "fortigenesis", South African Journal of Psychology 25(2), 81-89.

Strümpfer, J.W., 2006, 'The Strenghts Perspective: Fortigenesis in Adult Life' Journal for Social Indicators Research 77(1), 11-36. http://dx.doi.org/10.1007/s11205005-5551-2

Swinton, J. \& Mowat, H., 2006, Practical Theology and Qualitative Research, SCM Press, London.

Thurneyson, E., 1957, Die Lehre von der Seelsorge, 2nd edn., Theologischer Verlag, Zürich.

Van der Ven, J.A., 1990, Entwurf einer empirischen Theologie, Kok, Kampen.

Van der Ven, J.A., 1993, Ecclesiologie in context, Kok, Kampen.

Vahanian, G., 1961, The Death of God, George Braziller, New York.

Vos, C. \& Pieterse, H.J.C., 1997, Hoe lieflik is u woning: Studies in praktiese teologie, Raad vir Geesteswetenskaplike Navorsing, Pretoria.

Wiersinga, H., 1972, Verzoening als verandering, Bosch \& Keuning, Baarn. 